\title{
Analysis and Practice of Urban Wetland Construction Technology in Mining Subsidence Water Area
}

\author{
Xueliang $\mathrm{Li}^{1,2}$ \\ ${ }^{1}$ China Coal Science and Technology Ecological Environment Technology Co. , Ltd., 100013, Beijing, China; \\ ${ }^{2}$ China Coal Research Institute, 100013, Beijing, China
}

\begin{abstract}
The mining of underground coal resources has a great impact on the ecological environment, especially in the high groundwater level area in the East, the mining subsidence has a more severe impact on the surface water, resulting in serious surface water, and the feasibility of restoring the original land function is poor. Based on the analysis of the characteristics of mining subsidence water, this paper puts forward the key technology of urban wetland construction, and analyzes it combined with engineering examples. The results show that: in the mining subsidence water area around the city, relying on the geographical advantages and abundant secondary wetland resources of coal mining subsidence, we can shape the regional tourism image, focus on the construction of Urban Wetland Park and ecological wetland, expand the urban service function of wetland in the aspects of leisure, tourism, education and tourism, as well as the rainwater storage and water purification function of wetland. This study provides a reference for the construction of similar mining cities.
\end{abstract}

\section{Introduction}

As a unique ecosystem formed by the interaction of water and land on the earth, wetland is known as "the kidney of the earth", "the birthplace of civilization" and "gene pool of species". It plays an irreplaceable role in resisting floods, regulating runoff, improving climate, controlling pollution, beautifying the environment and maintaining regional ecological balance. It is an important material basis for human survival and social sustainable development.

Over the years, China has made some progress in many aspects of wetland research, but most of the research only focuses on the study of the ecological environment of the primary wetland ${ }^{[1-4]}$. The research on the secondary wetland of coal mining subsidence pays attention to the environmental improvement of the secondary wetland itself. How to coordinate the construction of the secondary wetland in the mining subsidence water area with the planning of coal mining and mining city construction, and realize the sustainable development of the wetland and the city is relatively less, which needs to be further strengthened.

\section{Characteristics of mining subsidence water}

The construction of urban wetland function in coal mining subsidence area must be based on the analysis of regional mining subsidence characteristics, detailed investigation and analysis of mining area geological and topographic characteristics, hydrological conditions and water distribution, regional mining and surface subsidence, coal mining planning and time sequence, etc., and combined with mining subsidence prediction, make clear the regional mining subsidence stability, and then carry out governance zoning ${ }^{[5-6]}$. Among them, it is very important to master the influence mode and characteristics of mining subsidence on surface water and groundwater, which is the premise of carrying out other follow-up work.

\subsection{Impact of mining subsidence on surface water system}

The old mined out areas in some resource-based cities are widely distributed and densely distributed. In the long history of coal mining, the mining activities in different depths and areas of coal bearing strata and coal seam outcrops have left countless old goaf areas, which have gradually stabilized after years of strata settlement and compaction. Because the mining area is multi coal seam mining, that is, the coal seam is mined from the shallow to the deep, from the upper layer to the next layer, resulting in frequent activation of the old mining area, which not only makes the surface continuously appear subsidence pits, but also increases the surface subsidence area. When

Corresponding author: 371986152@163.com 
the local surface subsidence value is greater than the groundwater depth in the dry season, ponding will occur [7-10]. With the increase of mining years, the water area of perennial water pit in coal mining subsidence increases gradually. Because of the existence of these subsidence pits, the surface runoff is changed. The surface runoff flows along the surface topography and becomes the surface runoff flowing into the subsidence pit confluence.

The level of surface water table is related to many factors, such as surface topography, atmospheric rainfall, distance from surface water body, surface permeability property and structure of quaternary system, interference of human activities (industrial and agricultural water, mining drainage, etc. ${ }^{[11-12]}$. The surface water caused by mining subsidence is usually divided into seasonal ponding and perennial ponding. According to the disturbance degree of mining subsidence to the land, generally, moderate damage causes seasonal water logging, seriously affects the growth of surface vegetation, and aggravates soil and water loss; severe damage causes perennial water accumulation, vegetation can't grow, and terrestrial ecosystem evolves into aquatic ecosystem.

\subsection{Analysis of ecological water supply characteristics}

The relationship of ecological water supply after coal mining subsidence is divided into new goaf and old goaf due to subsidence time sequence. For the old goaf, due to the long-term surface confluence and aquatic organism growth and metabolism, a layer of silt aquiclude will gradually form at the bottom of the water after the water accumulated in the mining subsidence area, which weakens the connection between the water body of the subsidence pit and the shallow groundwater. Generally, the water body in the old mining subsidence area is only closely related to surface runoff and river discharge. In general, in the early stage of urban wetland water construction, the corresponding anti-seepage treatment is carried out in the wetland Lake area. Therefore, in the later stage of urban wetland construction, the water body may only be closely related to surface runoff and river discharge due to the influence of both natural and human factors.


Fig. 1. Comparison of surface water and groundwater level in wetland (Nanhu Lake, Tangshan)

\section{Key technologies of urban wetland construction}

The construction technology of urban wetland in mining subsidence waterlogging area is aimed at the problems of large-scale surface water accumulation and mining and urban waste discharge caused by coal mining subsidence in high water table mining area, resulting in the destruction of land, water body, landscape and other ecological environment elements and serious water and soil pollution in mining subsidence area. Through the analysis of regional mining subsidence characteristics and stability, coal mining and urban wetland construction cooperation The water area of coal mining subsidence area will be developed into an artificial wetland with urban service function, which will change the regional microclimate, significantly improve the ecological environment quality of mining area, and lead the coal mining city construction from "back Lake" to "face Lake" The development direction of "supporting the lake" strongly supports the ecological civilization and livable construction of mining cities.

Table 1. Analysis of key technologies for wetland construction

\begin{tabular}{|c|l|}
\hline key technology & \multicolumn{1}{c|}{ Core content } \\
\hline $\begin{array}{c}\text { Coordinated planning } \\
\text { technology of coal mining } \\
\text { and wetland construction }\end{array}$ & $\begin{array}{l}\text { According to the principle of wetland habitat construction, engineering nature, } \\
\text { construction sequence, engineering layout and mining stability, the zoning planning } \\
\text { of urban wetland construction is carried out. Combined with the overall urban } \\
\text { development planning, the wetland construction planning layout and construction } \\
\text { sequence arrangement are defined. }\end{array}$ \\
\hline $\begin{array}{c}\text { Construction and } \\
\text { maintenance technology of } \\
\text { urban wetland water area in } \\
\text { Subsidence Area }\end{array}$ & $\begin{array}{l}\text { Combined with regional hydrogeological conditions and water system distribution, } \\
\text { urban wetland Lake expansion, seepage control, bank protection, pollutant control, } \\
\text { water purification, water system communication and pollution source treatment, } \\
\text { water maintenance engineering and facilities construction are carried out. }\end{array}$ \\
\hline $\begin{array}{c}\text { Land area construction and } \\
\text { urban function development } \\
\text { technology of wetland in } \\
\text { Subsidence Area }\end{array}$ & $\begin{array}{l}\text { According to the characteristics of topography and the situation of solid waste } \\
\text { stacking, the land area construction of wetland is carried out by means of digging } \\
\text { deep and laying money, pre padding, solid waste pollution prevention and mountain } \\
\text { Landscaping; combined with the relevant planning of urban development, the } \\
\text { service function development of wetland city integrating residence, culture and } \\
\text { education, sports and leisure is carried out. }\end{array}$ \\
\hline
\end{tabular}




\begin{tabular}{|c|c|}
\hline $\begin{array}{l}\text { Plant selection and } \\
\text { landscape construction } \\
\text { technology of urban } \\
\text { wetland in Subsidence Area }\end{array}$ & $\begin{array}{l}\text { Plant selection and landscape construction technology of urban wetland in } \\
\text { Subsidence Area: natural screening, long-term trial planting screening and } \\
\text { introduction screening are combined to screen plant species in urban wetland. Based } \\
\text { on the degree of surface stability and the requirements of ecological landscape } \\
\text { layout of urban wetland, the community configuration mode of different wetland } \\
\text { landscape types, such as water body, island, surrounding of embankment buildings } \\
\text { and ground cover plants, is constructed. }\end{array}$ \\
\hline
\end{tabular}

Its technical functions are embodied in the following three aspects: ecological function: the construction of urban wetland in subsidence area can fundamentally solve the problems of land, water, vegetation, landscape and other ecological elements in mining area and soil and water pollution, form a stable ecosystem with complex and benign succession, and become an urban wetland park with ecological protection, popular science education, natural interest and leisure tour as the main contents; city The construction of urban wetland in subsidence area makes the suburban sewage overflowing, dirty and barren mining subsidence area become the "green lung" of the city, which provides support for the realization of ecological livable construction and sustainable economic and social development of mining cities; Land value-added function, The construction of urban wetland in subsidence areas has led the development of coal mining city construction to coal mining subsidence areas, solved the bottleneck of construction land,reduced the occupation of fertile land for urban construction. Therefore, the value of land has been increased, land intensive use has been realized, and the development of mining city has provided a broad space.

\section{Case study}

\subsection{Overview of the project area}

Tangshan Nanhu City Central Ecological Park is located in the south of Tangshan City, only $670 \mathrm{~m}$ away from the city center, with an area of $28 \mathrm{~km}^{2}$. Before the transformation, the coal mining subsidence area was formed after more than 130 years of mining in Kailuan. Although the water area is large, the water depth in dry season is less than $1 \mathrm{~m}$, and some even have no water and dry. At the same time, because it is close to the urban area, the waterlogged subsidence area has become the discharge place of coal gangue, power plant ash, urban domestic waste and construction waste. In addition, some industrial and mining enterprises' production and domestic sewage discharge, the gangue spontaneous combustion releases sulfur dioxide and carbon monoxide, which causes serious damage to the ecological environment and natural landscape of the subsidence area, and gradually becomes a deserted land with few people. Over the years, large-scale renovation has been carried out for many times, and the ecological environment has been continuously improved. The wetland and its surrounding areas have gradually formed typical wetland vegetation types and wetland landscape, and become a place for migration and breeding of wild birds and recreation for Tangshan citizens.

\subsection{Main engineering construction}

(1) Water area construction

Water area construction includes Lake expansion project and water system maintenance project. Lake expansion project is the main part of the demonstration area, and also the core content of secondary wetland construction. After the use of Lake expansion and anti-seepage technology, the secondary wetland forms a relatively concentrated perennial water area of $391.49 \mathrm{hm}^{2}$, the average depth of wetland water is $2.5 \mathrm{~m}$, and the water storage capacity is 9.7873 million cubic meters. The construction of water conservation demonstration area mainly includes the construction of Qinglong river ecological canal in the West and Douhe River in the East. The construction length of Qinglong river is $5.2 \mathrm{~km}$, and the construction length of Douhe ecological canal is $6.7 \mathrm{~km}$, which provides guarantee for wetland water source.

(2) Pollution control

It mainly includes landfill closure greening, gangue and fly ash field treatment and landscaping. The treatment area of the garbage hill is $10.57 \mathrm{hm}^{2}$, and the pollution source is eliminated through site closure and covering, leachate treatment and landfill gas treatment; the vegetation greening area is about $13 \mathrm{hm}^{2}$, and the pollution source is eliminated by the treatment and greening of the garbage mountain, forming the landmark scenic spot of Danan lake ecological city. The treatment area of fly ash pond and coal gangue yard is $100 \mathrm{hm}^{2}, 4.2$ million cubic meters of fly ash and 2.8 million cubic meters of coal gangue are excavated. A gangue fly ash hill with a maximum of $30 \mathrm{~m}$ and an area of $24 \mathrm{hm}^{2}$ is formed by greening the waste rock and fly ash mountain with an area of $24 \mathrm{hm}^{2}$.

(3) Advance treatment

The advanced height control area is the protection coal pillar mining area of Jingshan railway and the planning and construction area of outdoor sports base on the south side of Jingshan railway, covering an area of $186 \mathrm{hm}^{2}$. In 2008, 1.728 million cubic meters of soil in the area of outdoor sports base was used to form a backfill area with an average pile height of $10 \mathrm{~m}$.

(4) Vegetation landscape construction

Vegetation landscape construction involves the whole demonstration area, including vegetation screening to vegetation configuration. 120 species of plants with drought resistance, water humidity resistance and salt alkali resistance were selected from the perspective of ecological adaptability by using wetland vegetation suitability screening method; 29 drought and barren vegetation varieties, 31 water and humidity resistant plants, 16 salt and alkaline plants, 26 plant diseases and insect pests resistance, and 13 shade tolerant plants were 
selected from the perspective of ecological adaptability There are 4 kinds of green trees, 12 kinds of flower color plants, 8 kinds of plants with both flower and fruit, and 12 kinds of plants with autumn leaves. On the basis of taking into account the urban landscape effect and ecological effect, seven wetland plant allocation modes were established, including water plant, island vegetation, embankment vegetation, road plant, building surrounding plant, ground cover plant and parking lot plant.

(5) Landscape construction of urban service function area

Architectural landscape mainly refers to the construction of anti deformation buildings conforming to the wetland landscape planning and adapting to the deformation of mining area. Wetland urban functional service areas mainly include culture, leisure and entertainment, municipal facilities, etc. Cultural landscape construction mainly includes fenghuangtai (garbage mountain), Longquan Temple, citizen square, etc.; leisure and entertainment landscape mainly includes sports green space, Swan Lake, cruise wharf, hydrophilic trestle, children's paradise, water screen film, photography base, International Conference Center, purple Swan villa, etc.; the landscape of municipal facilities mainly includes parking lot, sales booth, bus stop in the park, etc.



Fig. 2 urban wetland subsidence caused by coal mining in Nanhu, Tangshan

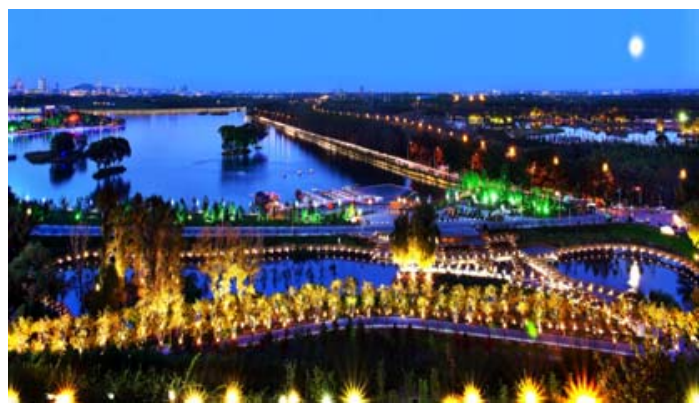

Fig. 3 night view of urban wetland in Nanhu coal mining subsidence, Tangshan

\subsection{Benefit analysis}

Through water area construction, pollution control, mountain landscaping and other technologies, the suburban sewage overflowing, dirty and barren coal mining subsidence area has become an urban wetland park, forming a complex and benign positive succession of stable ecological system, realizing the historic great changes from waste to treasure, from inferior position to advantage, from decay to magic, from "dark" to "blue", and to promote the development and utilization of surrounding areas, so as to improve Living conditions, improving urban grade, solving land bottleneck and solving urban construction funds have created huge ecological, economic and environmental benefits.

\section{Conclusion}

(1) The research on the construction technology of urban wetland in coal mining subsidence water area is the scientific and technological needs of a series of national sustainable development measures, such as national low-carbon ecological city pilot, ecological garden city construction, sustainable development experimental area, national ecological demonstration area and so on. The research results can provide scientific and technological support for promoting the coordinated and orderly development of mining city ecosystem, improving the quality of urban ecological environment, urban ecological construction and green transformation.

(2) The construction of urban wetland in mining subsidence water area is an arduous and complex system engineering. In the next step, we need to focus on the construction and water maintenance of secondary wetland water area in mining subsidence area, the comprehensive pollution control, the coordinated construction of coal mining with different degree of stability and urban secondary wetland, and the multi-level remote sensing information extraction method for urban subsidence In addition, the research and engineering application of ecological system evolution law and comprehensive selection method of suitable plant species in urban secondary wetland were carried out.

\section{References}

1. Y. Ma, B. Zhangi, Q. Xu, et al. Forestry science, 55, 140(2019)

2. J. Zhu, Y. Zhou, S. Wang, et al. Journal of Remote Sensing, 23, 971(2019)

3. Y. Wu, G. Zhang. Acta ecology Sinica, 38, 2588(2018)

4. W. Yu, G. Zhou, D. Chi, et al. Water saving irrigation, 1, 19 (2007)

5. S. Li, N. Diao. Mine surveying, 44, 65(2016)

6. Y. Lug, S. Li. Metal mine, 04, 56(2015)

7. H. Wan, L. Shen. Resource science, 27, 20(2005)

8. Z. Bai, W. Zhou, J. Wang, et al. Chinese Journal of land science, 32, 1(2018)

9. W. Xiao, J. Chen, Z. Hu, et al. Coal science and technology, 45, 184(2017)

10. S. Li, X. Lig, L. Men, et al. Coal science and technology, 48, 60(2020)

11. X. Guo, G. Dong, H. He, et al. Water conservancy and hydropower technology, 48, 60 (2017)

12. Y. Fu, Z. Hu, W. Xiao, et al. Wetland science, 14, 671(2016) 